\title{
THE CONCEPT "LONDON” AS A TEMPORAL CODE OF LINGUOCULTURE IN THE LITERARY AND REGIONAL WORK OF PETER ACKROYD "LONDON: THE BIOGRAPHY”
}

\author{
Sultan Kaliev ${ }^{1}$, Batima Zhumagulova ${ }^{2}$ \\ ${ }^{1}$ Mr. Sultan Kaliev, Master student, Kazakh Ablai khan University of International Relations and \\ World Languages, The Republic of Kazakhstan, Almaty, KAZAKHSTAN, 8ff8@inbox.ru \\ ${ }^{2}$ (Co-author) Batima Zhumagulova, candidate of philological sciences, associate professor, \\ Kazakh Ablai khan University of International Relations and World Languages, The Republic of \\ Kazakhstan, Almaty, KAZAKHSTAN, youmbs@mail.ru
}

\begin{abstract}
This article analyzes the spatial-temporal code of lingua-culture as one of the components of the general cognitive-matrix model of the structure of the concept "London" in the literary and regional work of Peter Ackroyd "London: The Biography". This approach implements integration of cognitive-matrix modeling of the structure of the concept and the system of codes of lingua-culture (anthropomorphic, temporal, vegetative, spiritual, social, chemical, etc.) The space-time code of the concept "London" is presented as a system of conceptual metaphors, reflecting various aspects of the space-time continuum of a given metropolis: 1) London as a labyrinth of time (MEASURE OF TIME), historical analogies with ancient cities(BABYLON, ROME, JERUSALEM); 2) City in periods: TROUBLED TIMES (A SOLID WALL OF FIRE, OVERHEATED CITY, CITY IN TEARS, TRIPLE TREE) / HOLY TIMES (HEAVENLY GATES, LAND FROM GOLGOTHA, AURA OF HOLY TIME, ELIXIR OF LIFE); 3) London as a labyrinth of space (WATER OBJECTS: A SEA, AN OCEAN, THE THAMES, NIAGARA; LABYRINTH HALF OF STONE, HALF OF FLESH); 4) London time as a prison (TIME TURNS INTO PRISON, TIME IS NOT REDEEMABLE, NOT TIME-SPARED MONUMENTS).This study reveals the author's intention to present London as the metropolitan continuum that evolves in space and time, physically expressed by "vague buzz of the time itself... It impresses more than the roar of a storm or a waterfall, for there is a presence of human's will and conscious movement in it".
\end{abstract}

Keywords: concept, cognitive-matrix model, integrative approach, conceptual metaphor, lingua-culturology, cognitive linguistics, codes of lingua-culture, space, time, space-time continuum.

\section{INTRODUCTION}

The study of the urban concept "London" in the work of Peter Ackroyd "London: The Biography" is based on the notion of cognitive matrix by N.N. Boldyrev [Boldyrev, 2008, p. 5] and the system of codes of linguaculture by M.V. Pimenova [Pimenova, 2016, p. 131]. Reflection of space and time in the linguistic consciousness of the native speaker of language and culture is explored in the framework of cognitive linguistics as the main concepts of the linguistic picture of the world and also in literary criticism as a category of chronotope that performs the plot-forming function in an artistic work. It is possible to present an integrative approach to the study of the space-time continuum within the framework of a separate artwork based on the cognitive-matrix model.

Cognitive-matrix modeling is considered as a research technique in the system of cognitive-matrix 
analysis, which was proposed by N.N. Boldyrev to study units of a special format that cannot be correlated with standard knowledge [Boldyrev, 2008, p. 7]. The cognitive matrix combines knowledge of various aspects of the phenomenon into a system of different cognitive contexts, which in turn are represented integratively by its components in the frame of the whole complex concept. These contexts have the ability to differ at the level of complexity and their content can be modified from the ordinary to the expert one [Boldyrev, 2009, p. 49];

The integrative approach as a synthesis of the cognitive matrix (N.N. Boldyrev) and linguistic codes (M.V. Pimenova) was realized by the model presented by Figure 1. Each component of the cognitive-matrix model introduces a specific cultural code as a system of subcodes with linguistic means of expression.

FIG. 1 Intergrative Cognitive-Matrix Model (N.N. Boldyrev) As A System Of Linguistic Codes (M.V. Pimenova)

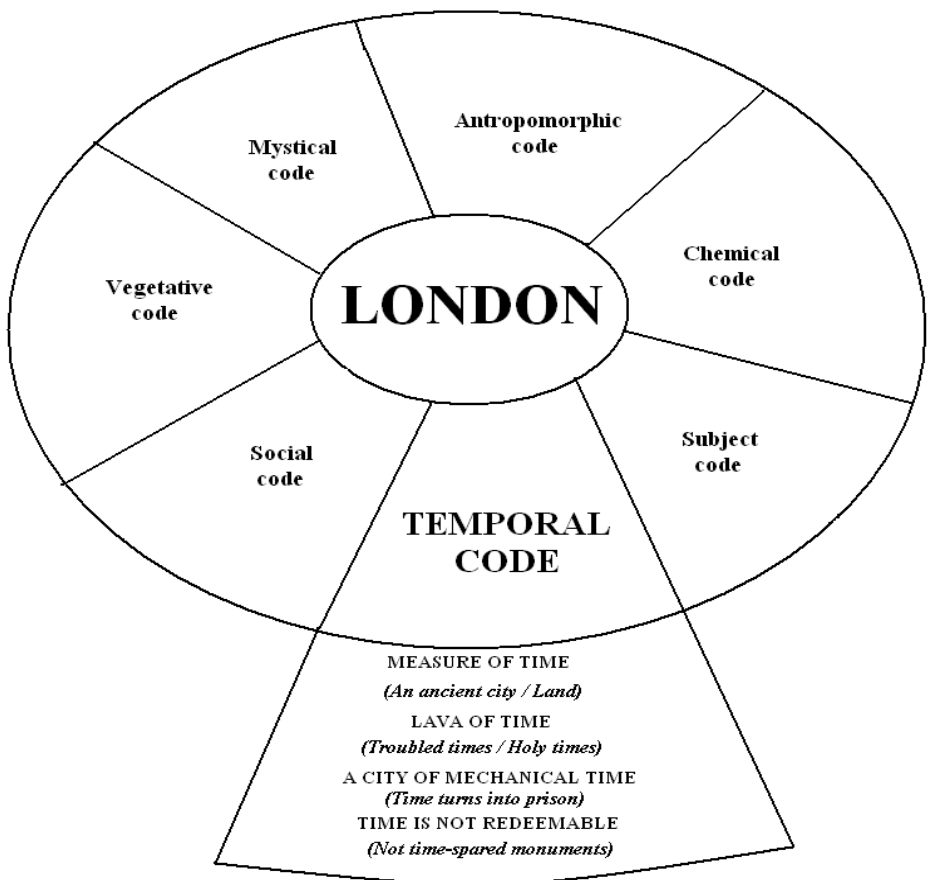

According to the theory of M.V. Pimenova, the culture code is a system of characteristics of objects in the world picture, connected by common aggregate categorical property. This is a kind of conceptual grid, using which the native speaker categorizes, structures and considers the surrounding world and his/her inner worlds. In the system of conceptual culture codes, the temporal culture code is allocated, which represents images by means of time designation. The temporal code of a culture is a set of representations associated with the division of the time axis into segments and with the relation of a person to time [Pimenova, 2016, p. 131]. Each national culture is distinguished by specific linguistic images, symbols, which form a special system of codes, with which the native speaker describes the world around him/her, using it in the interpretation of the surrounding world, as well as his/her inner world. Concepts of the inner world are usually represented in the language by the system of conceptual metaphors: structural, ontological and orientational. [Lakoff, 2004, p. 25]. The metaphor defines the ways in which a person perceives reality in culture. It is build through the comparison of a new object with the already known one and emphasizing their common characteristics. [Lakoff, 2004, p. 15]

Metaphor penetrates into everyday life, not only in language, but also in thinking and action. [Lakoff, 2004, p. 27]. Structural metaphors are used one highly structured concept to structure another. Orientational metaphors give a concept spatial orientation and base on the spatial opposition of the type "top - bottom", "inside - outside", "central - peripheral". They are based on our physical and cultural experience. A distinctive feature of ontological metaphors is ways of perception of events, activities, emotions, ideas as material entities and substances [Lakoff, 2004, p. 35-49].

In the historical literary work of Peter Ackroyd "London: The Biography" the metaphor plays a significant role, because metaphors are used as a thought phenomenon. Concerning the temporal code of the concept "London", several aspects of time expressed by conceptual metaphors were discerned:

1) Measure Of Time 
2) Axiological Aspect Of Time

3) Dynamics And Structure Of Time

4) Negative Impact Of Time On People

\section{SECTION 1}

According to Peter Ackroyd: In medieval documents ancient London customs were declared to be "from time out of mind, about which contrary human memory does not exist"; or an object might be classified as standing "where it now stands for a longer time than any of the jurors can themselves recall." The masons discover a great tomb within the ancient foundations of the church, in which rests the unblemished corpse of a pagan judge who speaks thus: "How long I have lain here is from a time forgotten. It is too much for any man to give it a length". These were ritualised, or standardised, phrases suggesting that the earliest measure of time was human memory itself. [Ackroyd, 2001, p. 770]; This ontological metaphor provides a reference to ancient civilizations, London is likened to a number of ancient cities and states, both real and imaginary, in the aspects of sin and virtue: The images of Babylon and Sodom therefore, more than enough, but the city symbolizes hell in a different sense, deeper. West Smithfield, after the foundation of St. Bartholomew-the-Great in the early twelfth century, witnessed as many miracles as any other plot in Rome or Jerusalem. [Ackroyd, 2001, p. 57]. Add here the biblical metaphor of the Thames as a dark river of the underworld of Golgotha: The number of human skulls found in Chelsea has one of the names of "our Celtic Golgotha". [Ackroyd, 2001, p. 641]. Another evidence that human memory structures time by events of a different plane is the metaphor: In the bell-eared euphony sacred time was crowned with the worldly. [Ackroyd, 2001, p. 58]. Time is fixed by certain affairs and occupations of citizens: "at the hour of the sermon", "at the hour of the auction, when the merchants converge on the Royal Exchange." Along with this, during many centuries, a kind of everyday memory of the community acted. The memory of time includes both TROUBLED TIMES and HOLY TIMES.

\section{SECTION 2}

The AXIOLOGICAL ASPECT OF TIME is presented by ontological images TROUBLED TIMES / HOLY TIMES which provide the opportunity to comprehend events, actions, ideas and emotions, as well as perceived sensory objects and entities. They open a whole series of phenomena that now exist as part of the present. The city is peculiar to keep everything in itself. That is why London is a triumphant, containing an abundance of events that form part of the city's history.

Figures 2 and 3 show the chronology of the facts in metaphorical conceptualization through dialectic of space and time. The facts are associated with developments affecting the whole nation and human perfection of the spiritual life and morality.

FIG. 2 Map: Troubled Times (Time-And-Space-Continuum Of London In Metaphorical Conceptualization)

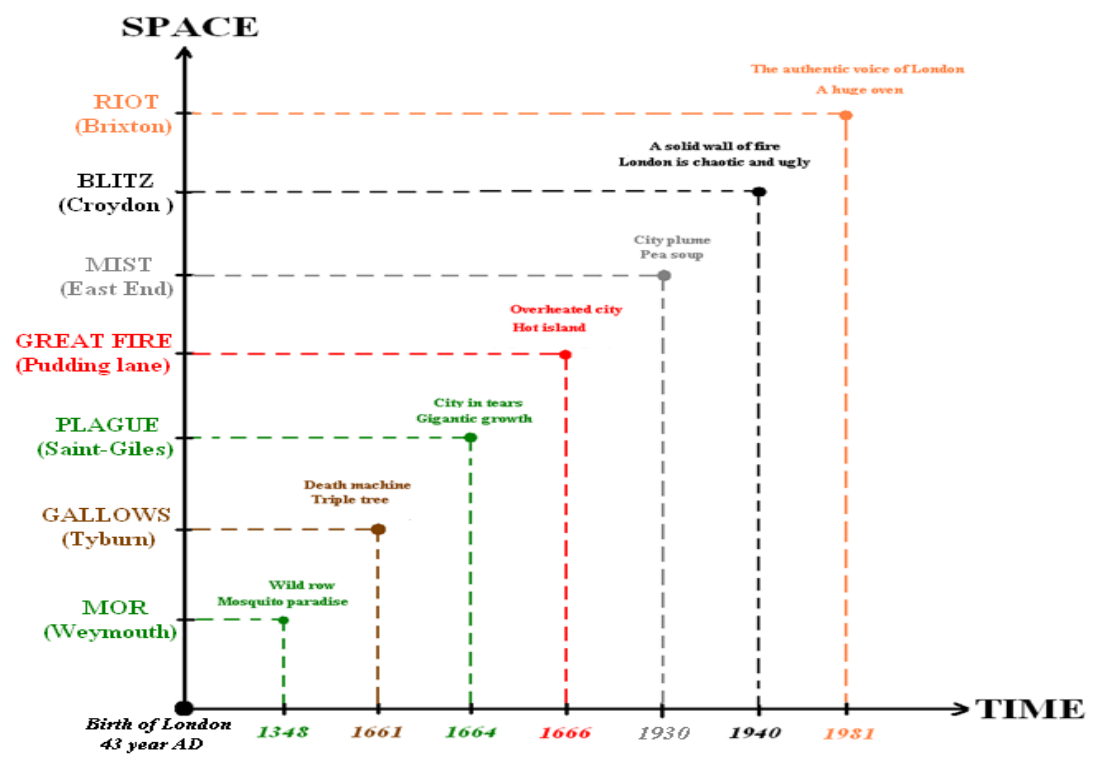


2.1 WILD ROW: This structural metaphor tries to give an idea that in the years of the epidemic a huge number of people died, the epidemic so quickly killed $40 \%$ of the population, which had to be buried in a chaotic order. Many were buried in a no-man's wasteland behind an urban wall known as "Field of Forgiveness" and "Wild Row" now part of Clarkenwell Road after Charterhouse. [Ackroyd, 2001, p. 242].

2.2 MOSQUITO PARADISE: This expression gives a direct reference to the moraine that occurred in 1348 , which was accompanied by malaria, during which various diseases were transmitted. The swamps and open drainage ditches of the capital turned into a "mosquito paradise" that caused a "fever", that is, malaria. [Ackroyd, 2001, p. 242].

2.3 DEATH MACHINE: The metaphor describes the instrument for execution as an impeccable mechanism for punishment. It was a platform with three parallel bars on supports, for which it received such a threatening title. A mobile "death machine" was brought to Newgate Street with the help of a horse harness. [Ackroyd, 2001, p. 301].

2.4 TRIPLE TREE: Another metaphor representing an attribute for executions, on each of the three connecting columns of bars, there were eight people, so that twenty-four criminals could be hung at the same time. True story about how the famous triple tree near Paddington was torn up with a root and was killed by some evil spirits, as well as the cry of Jack Ketch, who was left without work. [Ackroyd, 2001, p. 182]

2.5 GIANT GROWTH: In this expression, Peter Ackroyd tries to equate the plague as something disgusting and ugly; in it he sees a huge built-up edge that poisons almost the entire city.

Truly it is a "tumor", and "giant growth". Shaken by fever, choking from the ashes, the body is attracted from the Great Plague to the Great Fire. [Ackroyd, 2001, p. 13].

2.6 CITY IN TEARS: In the years of "Black Death", the city like a human body was suffered from within by severe poisoning; the metaphor describes the state of London in one of its hard times.

London is tormented by a "fever", and it "is all in tears. "[Ackroyd, 2001, p. 246].

2.7 OVERHEATED CITY: Here the author with the help of metaphor tries to convey the most accurate position of the city during the Great Fire, as the flame enveloped literally the whole city, the word "overheated" gives food for imagination to recreate this dramatic picture. Thus, thanks to a curious metaphorical leap, the fire turned into a source of strength and energy, began to be perceived as a powerful sporadic outbreak, and sort of "discharge" of the overheated city. [Ackroyd, 2001, p. 270].

2.8 A HOT ISLAND: This metaphor describes the "nickname of the city" which he received during the Great Fire. The fire simply saturated its presence with air and earth, as a result of which it seemed like a hot island. It was a city where "the fire is irresistibly bursting", and in the 20th century it was called a "hot island". [Ackroyd, 2001, p. 270].

2.9 CITY PLUME: Fog is an integral part of the whole of London, in the 1930s it so strongly enveloped the city that people really thought London was wearing a "head piece". It was at that time in the meteorological records that became known as the "great plume". [Ackroyd, 2001, p. 515].

2.10 PEA SOUP: Naturally, this metaphor cannot be taken literally. However, in a figurative sense, it ideally represents the time when a massive thick of mist fell on the city and apparently resembled pea soup. However, sometimes in the 1920s, and in the 1930s, the capital suddenly plunged into "pea soup". [Ackroyd, 2001, p. 517].

2.11 A SOLID WALL OF FIRE: This metaphor was used by one observer, who was on the roof of the English Bank during the bombing of the city. He recalled: "It seemed like the whole of London was burning! Around, wherever you look, a solid wall of fire." [Ackroyd, 2001, p. 865].

2.12 LONDON IS CHAOTIC AND UGLY: Peter Ackroyd has always represented the city as an organism that has borne all the ups and downs. At the heart of this metaphor is the fate of London during the Second World War. The city, like a man suffering from suffering, pain and beating, has become ugly and terrible outside. London became chaotic and ugly, anxiety and insomnia were read on the faces of the townspeople. [Ackroyd, 2001, p. 869].

2.13 THE AUTHENTIC VOICE OF LONDON: Human cries, moans, laughter, etc. merge into a common sound, and thereby creating an atmosphere of a single sound, London's voices formed the basis of the image and were inherent in the moment of the loudest riot that occurred in 1981.A loud, indefinite rumble, rising to a roar and accompanied by a strange universal movement, is the authentic voice of London. 
[Ackroyd, 2001, p. 475].

2.14 A HUGE OVEN: The riot is one of the main events in the history of London. The most large-scale are the unrest of 1981. The revolt so quickly flared up and continued to burn like a heated oven, as a result of which the author used this metaphor as the embodiment of the movement of the whole London crowd. The nineteenth century inherited all these features, but in the huge "oven" or gigantic "growth" that London has become, the crowd has become increasingly impersonal. [Ackroyd, 2001, p. 476].

FIG. 3Map: Holy Times(Time-And-Space-Continuum Of London In Metaphorical Conceptualization)

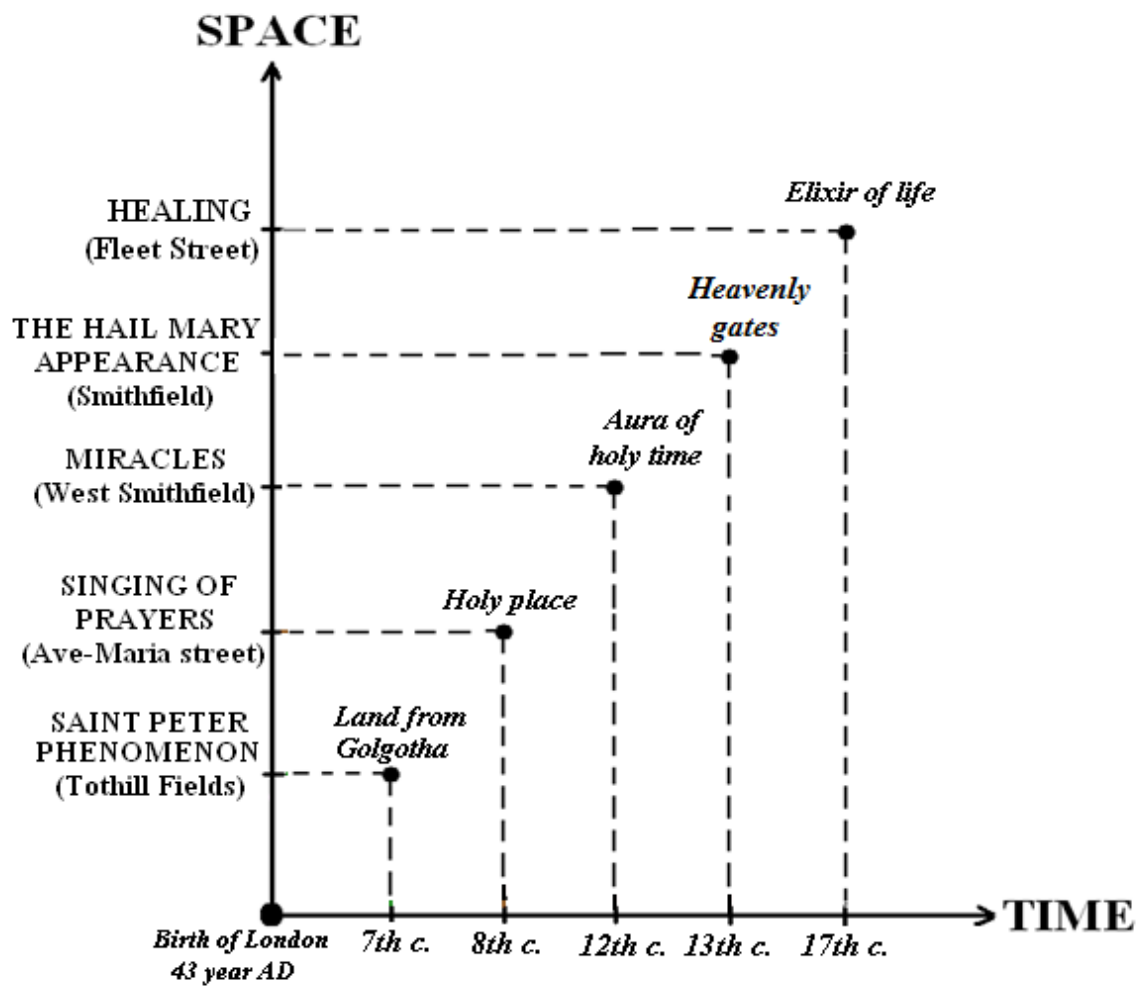

2.15 LAND FROM GOLGOTHA: This metaphor tells about miracles that took place in the 7th century near the church of Saint Peter. On the night before the consecration of the first Saxon church built on this site, Saint Peter himself appeared to a fisherman and was transported across the river from Lambeth, then he crossed the threshold of a new church and was immediately flooded with light. Edward the Confessor is an anonymous, after which he ordered the erection of a large abbey here. It became a depository of sand from Mount Sinai and land from Golgotha. [Ackroyd, 2001, p. 56].

2.16 HOLY PLACE: Describes the state of such streets as Paternoster Row, Ave Maria Lane, Amen-Court and Creed Lane during the 8th century. In these places one could always hear prayers. In addition, the spirit of antiquity resides in them, as if forcing people to relive their history from time to time. Perhaps this area is a "holy place", connecting the city with eternity. [Ackroyd, 2001, p. 61].

2.17 AURA OF HOLY TIME: This ontological metaphor carries the reader into the distant 12th century, and tells of miracles taking place at the church of Saint Bartholomew. For example, a certain Woolmer, a cripple, moving on two supports, everywhere worn with him, was brought to Saint Bartholomew in the basket, he fell prostrate before the altar and healed. Many of these miracles occurred on the day of Saint Bartholomew, so that in the city constantly acted aura not only of holy places, but also of holy time. [Ackroyd, 2001, p. 60].

2.18 HEAVENLY GATES: Another expression describing the sanctity of the church of Saint Bartholomew. Here in the 13th century, the Blessed Virgin appeared to a layman and said: "I will listen to your vows and prayers and will not deprive you of my favor forever and ever. "These words resonate with other London stories of miracles and visions; here among the urban soot and stench, the "heavenly gates". [Ackroyd, 2001, p. 58].

2.19 ELIXIR OF LIFE: Here Peter Ackroyd narrates that in the 17th century, William Salmon - a 
IJASOS- International E-Journal of Advances in Social Sciences, Vol. IV, Issue 10, April 2018

famous healer and conjurer, lived on Fleet Street. At that time, he invented the elixir of life, which healed any man. He was born in the summer of 1644 and at that time he began to sell his own "Elixir of Life". [Ackroyd, 2001, p. 252].

\section{SECTION 3}

The ontological metaphor LAVA OF TIME characterizes the STRUCTURE AND DYNAMICS OF TIME AND SPACE of temporal continuum of London using one concept to disclose the other. Peter Ackroyd equates the nature of time with a particular phenomenon, namely, the mysterious one. It seems that it does not flow continuously in one direction, but now and then wraps it back, goes back, like a stream of flamy lava. Sometimes it moves evenly, and then suddenly rushes forward in a jerk.

It resembles not so much a river or stream as a stream of lava erupted from some unknown fiery source. [Ackroyd, 2001, p. 778]. The dynamics of time in the image of lava is enhanced by the acoustic metaphor of the time VAGUE BUZZ OF THE TIME ITSELF. One of the most important features of London is its quiet unceasing bellow, which is not like other noises. The author perceives this constant din as a vague buzz of the time itself, as it senses a presence of human's will and conscious movement: This is his low, incessant roar, not like any other sound; It impresses more than the roar of a storm or a waterfall, for there is a presence of human's will and conscious movement in it, and I admit that this sound reminds me of the vague buzz of the time itself. [Ackroyd, 2001, p. 99]. Time like erupting lava correlates with the city space in images of water objects: A SEA, AN OCEAN, THE THAMES, NIAGARA, emphasizing the scale, the extent of the metropolis and the diversity of types of inhabitants of London comparable to the abundance and diversity of life forms in the ocean: London has always been a vast ocean in which survival is not certain. [Ackroyd, 2001, p. 218]. And the muted, sustained and unending roar of the city is akin to the noise of the Niagara Falls: At a distance of half a mile they turned into a low, steady, incessant roar, resembling the noise of a waterfall; It was the real Niagara of the vote. [Ackroyd, 2001, p. 218]. The structural metaphor of LABYRINTH HALF OF STONE, HALF OF FLESH emphasizes urban crowdedness, chaotic and tortuous streets, as London consists of many lanes, driveways, courtyards and highways that form an endless labyrinth, continuously changing and growing in breadth: London is a labyrinth half of stone, half of flesh. [Ackroyd, 2001, p. 14].

\section{SECTION 4}

This section represents NEGATIVE IMPACT OF TIME ON PEOPLE and their reaction on it. The ontological metaphor A CITY OF MECHANICAL TIME shows London as the center of mass production in the 19th century, constantly in need of human labor. City sucks all the energy out of people, and then "spews" them and replaces them with others, like a new lubricated watch movement: London became a city of mechanical time, a city of rapidity for the sake of speed. [Ackroyd, 2001, p. 665]. The ontological metaphor TIME TURNS INTO PRISON emphasizes the power of time, the attribute of which is the unceasing human labor, depriving the workers of freedom, distractions and joys in life. By becoming mechanisms, the townsfolk turned into parts of the London's clock: As soon as the machine guns are being seen, the townspeople become the details of a gigantic clock - London. And then time turns into prison. [Ackroyd, 2001, p. 772]. Ontological metaphors TO SKIP TIME and TO BURN TIME show the attempt of Londoners to avoid the negative influence of the time factor, briefly forget about time and how to "jump" it with the help of dancing and singing. A dance can invariably serve as a refugee for Londoners from encroachments of watches with their mechanical time; That is, at least, a way to "skip" time. [Ackroyd, 2001, p. 773]. However, TIME IS NOT REDEEMABLE: London becomes the epitome of time itself. Great streams of thought and reason never stop their running. In the words of T.S. Eliot, the poet, "time is not redeemable". [Ackroyd, 2001, p. 99].

\section{CONCLUSION}

The analysis allow to draw the following conclusions. The space-time code of culture reveals London as urban space-time continuum that represents the development of the metropolis as a synthesis of time, space, events, and ideas through a system of conceptual metaphors. Metaphorical images show various aspects of time: memory as a MEASURE OF TIME (HUMAN MEMORY AS a MEASURE OF TIME), AXIOLOGICAL ASPECT OF TIME consisting of events of different plan (HOLY TIMES, TROUBLED TIMES); THE DYNAMICS AND STRUCTURE OF TIME (LAVA OF TIME), in correlation with the characteristics of the space (A SEA, AN OCEAN, THE THAMES, NIAGARA, LABYRINTH HALF OF STONE, HALF OF FLESH), which reveal in the end "a presence of human's will and conscious movement in it". [Ackroyd, 2001, p. 99]; And NEGATIVE IMPACT OF TIME ON PEOPLE (A CITY OF MECHANICAL TIME, TIME TURNS INTO a PRISON). Like other codes the space-time code sets the culture specific system of etalons by which we divide, structure and evaluate the world around us. 


\section{REFERENCE LIST}

Ackroyd P. (2001) London: The Biography. London: Vintage Books.

Boldyirev N.N., AlpatovV.V.(2008) Kognitivno-matrichnyiy analiz angliyskih hristianskih toponimov // Voprosyi kognitivnoy lingvistiki. \#4. p. 5-15.

Boldyirev N.N. (2009) Kontseptualnaya osnova slova // Kognitivnyie issledovaniya yazyika. Vyip. IV // Kollektivnaya monografiya. - M. - p.25-78.

Lakoff Dzhordzh, Dzhonson Mark (2004) Metaforyi, kotoryimi myi zhivem: Per. s angl. / Pod red. i s predisl. A. N. Baranova. - M.: Editorial URSS.

M.V. Pimenova, O.N. Kondrateva. (2016) Kontseptualnyie issledovaniya. Vvedenie. Uchebnoe posobie. Moskva. Izdatelstvo «Flinta». 